\title{
Article \\ Benefits of Polyamide Nanofibrous Materials: Antibacterial Activity and Retention Ability for Staphylococcus aureus
}

\author{
Simona Lencova ${ }^{1, *}$, Kamila Zdenkova ${ }^{1}$, Vera Jencova ${ }^{2} \mathbb{}{ }^{10}$, Katerina Demnerova ${ }^{1}$, Klara Zemanova ${ }^{1}$, \\ Radka Kolackova ${ }^{1}$, Kristyna Hozdova ${ }^{3}$ and Hana Stiborova ${ }^{1, *}$ \\ 1 Department of Biochemistry and Microbiology, Faculty of Food and Biochemical Technology, \\ University of Chemistry and Technology, Technicka 3, 16628 Prague 6, Czech Republic; \\ zdenkovk@vscht.cz (K.Z.); demnerok@vscht.cz (K.D.); zemanovl@vscht.cz (K.Z.); kolackor@vscht.cz (R.K.) \\ 2 Faculty of Science, Humanities and Education, Technical University of Liberec, Studentska 1402/2, \\ 46117 Liberec 1, Czech Republic; vera.jencova@tul.cz \\ 3 Elmarco Ltd., Svarovska 621, 46001 Liberec, Czech Republic; kristyna.hozdova@elmarco.com \\ * Correspondence: lencovas@vscht.cz (S.L.); stiboroh@vscht.cz (H.S.); Tel.: +420-220-44-5196 (S.L.); \\ +420-220-44-5204 (H.S.)
}

Citation: Lencova, S.; Zdenkova, K.; Jencova, V.; Demnerova, K.;

Zemanova, K.; Kolackova, R.;

Hozdova, K.; Stiborova, H. Benefits of Polyamide Nanofibrous Materials: Antibacterial Activity and Retention Ability for Staphylococcus aureus.

Nanomaterials 2021, 11, 480. https:// doi.org/10.3390/nano11020480

Academic Editor: Krasimir Vasilev

Received: 28 January 2021

Accepted: 9 February 2021

Published: 13 February 2021

Publisher's Note: MDPI stays neutral with regard to jurisdictional claims in published maps and institutional affiliations.

\begin{abstract}
Although nanomaterials are used in many fields, little is known about the fundamental interactions between nanomaterials and microorganisms. To test antimicrobial properties and retention ability, 13 electrospun polyamide (PA) nanomaterials with different morphology and functionalization with various concentrations of $\mathrm{AgNO}_{3}$ and chlorhexidine (CHX) were analyzed. Staphylococcus aureus CCM 4516 was used to verify the designed nanomaterials' inhibition and permeability assays. All functionalized PAs suppressed bacterial growth, and the most effective antimicrobial nanomaterial was evaluated to be PA $12 \%$ with $4.0 \mathrm{wt} \% \mathrm{CHX}$ (inhibition zones: $2.9 \pm 0.2 \mathrm{~mm}$; $\log _{10}$ suppression: $8.9 \pm 0.0$; inhibitory rate: $100.0 \%$ ). Furthermore, the long-term stability of all functionalized PAs was tested. These nanomaterials can be stored at least nine months after their preparation without losing their antibacterial effect. A filtration apparatus was constructed for testing the retention of PAs. All of the PAs effectively retained the filtered bacteria with $\log _{10}$ removal of 3.3-6.8 and a retention rate of $96.7-100.0 \%$. Surface density significantly influenced the retention efficiency of PAs $(p \leq 0.01)$, while the effect of fiber diameter was not confirmed ( $p \geq 0.05)$. Due to their stability, retention, and antimicrobial properties, they can serve as a model for medical or filtration applications.
\end{abstract}

Keywords: polyamide; nanofiber; permeability; filtration apparatus; antimicrobial activity; Staphylococcus aureus; long-term stability

\section{Introduction}

Skin, being the largest organ of the human body, is exposed to various influences. From ancient times, skin injuries are among the most common types of health issues, resulting in the need for reliable treatment. The evolution of wound treatment led from materials that only stopped the bleeding to the development of functionalized materials with an antibacterial effect to prevent infections [1].

A wide range of pathogenic microorganisms can cause infections [2]. Furthermore, the microbiota present in the wound change during the infection process. In its initial stage, Gram-positive bacteria Staphylococcus aureus and Streptococcus pyogenes predominate, while Gram-negative bacteria, such as Escherichia coli and Pseudomonas aeruginosa, are usually detected in the final stages of infections and chronic wounds [3,4]. All of these bacteria can cause severe complications, and, therefore, various materials are used as wound dressings to reduce the risks associated with such infections.

These materials are expected to have specific characteristics. The ideal wound dressing should not only be a reliable barrier against foreign elements from the external environment 
but should also keep the injury moist, allow the exchange of gases, act against microorganisms, and remove redundant exudate. Thus, materials used as wound dressing must be safe for the patient, which means they must be non-toxic, non-allergenic, and either biodegradable or easily removable from the wound $[1,5,6]$. Fulfilling all of these requirements is not an easy task; therefore, recent research has focused on the development of functional wound dressings.

Nanomaterials with their unique properties can be very beneficial in this field. They make it possible to control external conditions at the injury site to ensure optimal cellular activity during the healing process, mostly adequate air access while preventing unwanted elements and microorganisms from the environment from entering the wound [6,7]. By fulfilling all of these requirements, nanomaterials are expected to have a barrier capability. Because of this, they can be used in the treatment of not only acute but also chronic skin injuries, in which the surface infections may result in a subcutaneous tissue infection and a directly life-threatening condition [1].

For a material qualify as a nanomaterial, it is necessary to know basic structural parameters. Nanomaterials differ in their behavior, depending on their fundamental characteristics resulting from the preparation process, even if they are made from the same polymer. Fiber diameter, surface density, air permeability, and fiber density (nanomaterial porosity) are the main characteristics [8]. Because of these parameters, materials differ in morphology, which is expected to affect their final properties, including the ability to act as a barrier. Nanofibrous materials were proven to be an effective barrier in several studies dealing with microbial filtration [9-13].

In addition to injury barriers, nanomaterials can act as carriers of substances with proven antimicrobial activity and thus inhibit the growth of microorganisms that are present. Nowadays, research is primarily focused on dressing materials for skin injuries enriched with various antimicrobial agents. The most common are as follows:

i. Antibiotics, such as ciprofloxacin [14], gentamicin [15], or tetracycline [16];

ii. Nanoparticles (NPs), such as Ag [17,18], $\mathrm{ZnO}$ [19], or $\mathrm{TiO}_{2}$ [20];

iii. Natural extracts, such as curcumin [21] or Hypericum perforatum [22];

iv. Antiseptics, such as chlorhexidine (CHX) $[23,24]$.

Silver and CHX are good examples of antimicrobial substances suitable for this purpose. Silver, with its proven antimicrobial properties against both Gram-positive and Gram-negative bacteria $[25,26]$, has enormous potential for treating skin wounds infected by resistant bacteria, for example, the methicillin-resistant strain of $S$. aureus [17]. CHX acts bactericidally by destroying bacteria cell membranes [27], and due to its antiseptic properties, it is mainly used in medicine and oral hygiene as a component in mouthwash [28]. Its antimicrobial effect in wound dressings, which was more significant for Gram-positive bacteria, has also been confirmed by several studies [23,29-31].

For an optimal antimicrobial effect of functionalized nanomaterials, it is crucial to have a homogenous nanofibrous structure and, at the same time, homogenous distribution of the antimicrobial compound. Polymers used for nanomaterial production vary in their ability to form homogenous materials. In general, functional wound dressings are usually made of biodegradable polyesters, such as polycaprolactone (PCL) or polylactic acid, with the main advantage of being used on the wound until their complete absorption [32]. However, it is quite challenging to obtain a homogenous structure in the production of polyester materials. On the other hand, uniform nanofibrous materials from polyamide (PA), a non-degradable synthetic polymer, can be prepared more easily and are considered to be more homogenous than, for example, PCL [33-35]. Due to their high mechanical resistance, PA materials are used in food packaging, the manufacture of joint replacements, and wound treatments in medicine $[6,32,36]$.

Because PA nanomaterials have considerable potential for use in the treatment of skin injuries, it is necessary to study microbial interactions with them before their common usage in healthcare. In our previous study [37], we reported how biofilm formation is influenced by the PA nanomaterials' morphology and $\mathrm{AgNO}_{3}$ functionalization, because 
biofilm development poses a major threat to wound healing. In this follow-up study, we aimed to analyze the other properties of PAs that reduce the risks of developing an infection. We designed a methodology for analyzing the materials' permeability for bacteria. Additionally, we tested the antibacterial activity and long-term stability of both nonfunctionalized and functionalized $\mathrm{PAs}$ with $\mathrm{AgNO}_{3}$ and $\mathrm{CHX}$, which has been tested sporadically in connection with PA nanofibers $[38,39]$. CHX-functionalized PAs were prepared and characterized within this study, the other PAs were prepared and characterized as part of our previous study [37]. The bacterium S. aureus, being a common part of natural skin microbiota and a frequent pathogen in skin wound infections, was chosen as a model microorganism. To our knowledge, we are the first who publish basic research about the retention ability of PA nanomaterials for a clinically relevant bacterium and, thus, increase their usage in several medical applications. Furthermore, the presented comprehensive design of testing microbiological safety and stability of PA nanofibrous materials is unique.

\section{Materials and Methods}

\subsection{Nanomaterial Preparation}

Nanofibrous PA materials were prepared from polymer solutions using a needleless electrospinning method in a Nanospider ${ }^{\mathrm{TM}}$ NS 1 S500 U device (Elmarco, Liberec, Czech Republic) as described in the study by Lencova et al. [37]. The electrospinning of the CHXadded layers was conducted from solutions containing 2.0 and $4.0 \%(w / w)$ chlorhexidine dihydrochloride (TCI chemicals, Tokyo, Japan). CHX was added to the prepared $12 \%$ PA solution and stirred at room temperature until its complete dissolution.

\subsection{Nanomaterial Characterization}

All non-functionalized PAs and PAs functionalized with $\mathrm{AgNO}_{3}$ were characterized in terms of surface density, thickness, air permeability, and fiber diameter in the study of Lencova et al. [37]. The same parameters for CHX PAs were characterized in this study. Briefly, the surface density was evaluated from $10 \times 10 \mathrm{~cm}$ samples taken from at least five different parts of the material; the thickness was measured with a Corp ID-C112XB device (Mitutoyo, Teplice, Czech Republic); air permeability was measured using a TEXTEST FX 3300 device (TexTest Instruments, Schwerzenbach, Switzerland). To evaluate fiber diameters, CHX PAs were sputter-coated with gold $(14 \mathrm{~nm})$, and pictures were taken using a scanning electron microscope (SEM) Tescan Vega3 SB Easy Probe (TESCAN, Brno, Czech Republic), and Nova NanoSEM 230 (Thermo Fisher Scientific, Waltham, MA, USA), respectively. The fiber diameter was evaluated from five pictures of each sample, at least 100 measurements from one sample in total, using the software NIS Elements (Nikon, Tokyo, Japan). Pore size of all 13 tested PAs was measured in this study; pore size was measured in a CFP-1200 AEL Capillary Flow Porometer (Porous Materials Inc., Ithaca, NY, USA) using the bubble point method.

\subsection{Bacterial Suspensions}

The Gram-positive bacterium Staphylococcus aureus CCM 4516 (eq. ATCC 6538), obtained from the Czech Collection of Microorganisms (CCM, Brno, Czech Republic), was used as a model microorganism in this study. S. aureus CCM 4516 is an isolate from a human lesion and is used as a control strain for testing disinfectants and antiseptics. Pure bacterial cells were resuspended in tryptone soy broth (TSB, Oxoid, Cheshire, UK) and then used for the experiments.

\subsection{Inhbition Assay}

A pure culture of S. aureus CCM 4516 was cultivated for $24 \mathrm{~h}$ at $37^{\circ} \mathrm{C}$ in TSB. The suspension's optical density (OD) was adjusted to $1 \mathrm{McF}$ arland $(\mathrm{McF})$. The tests were performed via the approaches described below. 


\subsubsection{Inhibition Zone Method}

For the inhibition zone method, we used a standard method adapted to the experiments. The plate count agar (PCA) plates were first inoculated by spreading five horizontal stripes of a bacterial suspension at a sufficient distance (approx. $1 \mathrm{~cm}$ ) from each other, and a piece of a sterile PA $(5 \times 5 \mathrm{~cm})$ was then placed onto the inoculated surface. At least three independent replicates were performed for each sample. After the incubation $(24 \mathrm{~h}$, $37^{\circ} \mathrm{C}$ ), inhibition zones $(\mathrm{mm})$ that formed around the PA were measured (from the edge of the PA).

\subsubsection{Inhibitory Rate Method}

A piece of a sterile PA $(5 \times 5 \mathrm{~cm})$ was placed into a test tube containing $10 \mathrm{~mL}$ of bacterial suspension with an approx. concentration of $10^{2} \mathrm{CFU} / \mathrm{mL}$ prepared by the serial decimal dilution of the suspension with OD $1 \mathrm{McF}$. After incubation for $24 \mathrm{~h}$ at $37^{\circ} \mathrm{C}$, the changes were compared by quantifying $\mathrm{CFU} / \mathrm{mL}$; the suspension was serially decimally diluted. The obtained dilutions were applied in $20 \mu \mathrm{L}$ droplets to a plate count agar (PCA, Oxoid, Cheshire, UK) in three parallels and incubated for $24 \mathrm{~h}$ at $37^{\circ} \mathrm{C}$. After the cultivation, grown bacterial colonies were counted and quantified [37]. Three independent replicates were performed for each sample. Bacterial suspensions without any added material were used as controls. Then, the inhibitory effect was calculated using the formula below (Equation (1)) [40]. From the CFU/mL determination, $\log _{10}$ suppression (CFU/mL) was assessed according to Equation (2) ( $\log _{10}$ suppression expresses the difference between bacterial growth in the control and the suspension with the PA, both after incubation under defined conditions).

$$
\text { Inhibitory rate }[\%]=\frac{\mathrm{CFU}(\text { control })-\mathrm{CFU}(\text { sample })}{\mathrm{CFU}(\text { control })} \times 100
$$

where CFU (control) is the number of $\mathrm{CFU} / \mathrm{mL}$ in the bacterial suspension itself and $\mathrm{CFU}$ (sample) is the number of $\mathrm{CFU} / \mathrm{mL}$ in the bacterial suspension with the added PA.

$$
\log _{10} \text { suppression }=\log _{10} \text { control }-\log _{10} \text { sample }
$$

where $\log _{10}$ control is the number of bacterial cells in the suspension itself and $\log _{10}$ sample is the number of bacterial cells in the suspension with the added PA.

\subsubsection{Long-Term Stability}

The above-described analyses were performed within one month after he PA's production. To verify the antimicrobial substances' long-term stability in functionalized PAs, both antimicrobial tests were repeated nine months after the preparation of the PAs. Between the measurements, PAs were stored at room temperature (approx. $21^{\circ} \mathrm{C}$ ) separately from each other in a sterile plastic box.

\subsection{Permeability Assay}

The assay was based on filtering the $S$. aureus CCM 4516 suspension through a PA membrane placed in a specially designed glass filter apparatus (Section 3.3.1). The nanofiber membranes, sterilized with ethylene oxide at room temperature for $12 \mathrm{~h}$ cycles (Anprolene, Andersen Products, Clacton-on-Sea, UK) and evaporated for at least a week [41], were used as filters with a diameter of $5 \mathrm{~cm}$ (corresponding to the apparatus diameter; the diameter of the resulting filter surface was $4 \mathrm{~cm}$ ). A total of $3 \mathrm{~mL}$ of bacterial suspension with OD adjusted to $1 \mathrm{McF}$ was filtered through them. After the filtration, the procedures detailed below were performed.

\subsubsection{Filter Cultivation}

The membranes were placed on Baird-Parker medium (BP, Merck, Darmstadt, Germany) as follows: one half of the PA with the filtration side up, and the other half with 
the bottom side up. After the incubation $\left(24 \mathrm{~h}, 37^{\circ} \mathrm{C}\right)$, bacterial growth on both sides of membranes was visually evaluated (S. aureus forms black-colored colonies at BP agar due to the reduction of potassium tellurite), compared, and recorded.

\subsubsection{Quantification of Bacterial Cells}

The bacteria both in the filtered suspensions and in the obtained filtrates were quantified as described in Section 2.4.2. At least three independent replicates were performed for each PA material. Then, $\log _{10}$ removal (CFU/mL) (Equation (3) [42]) and retention rate (Equation (4)) were calculated using the modified formula for inhibitory rate calculation [40].

$$
\log _{10} \text { removal }=\log _{10} \text { control }-\log _{10} \text { sample }
$$

where $\log _{10}$ control is the number of bacterial cells in the suspension itself and $\log _{10}$ sample is the number of bacterial cells in the suspension with the added PA.

$$
\text { Retention rate }[\%]=\frac{\mathrm{CFU}(\text { control })-\mathrm{CFU}(\text { sample })}{\mathrm{CFU}(\text { control })} \times 100
$$

where CFU (control) is the CFU/mL in the filtered suspension and CFU (sample) is the $\mathrm{CFU} / \mathrm{mL}$ in the final filtrate. When the final filtrate contained no cells, the sample was calculated to be $<1.0 \times 10^{1} \mathrm{CFU} / \mathrm{mL}$.

\subsubsection{SEM Analysis of PA Filters}

After the filtration of the bacterial suspension, PAs were rinsed with phosphatebuffered saline (PBS) and fixed with frozen absolute ethanol (Penta, Prague, Czech Republic) for $15 \mathrm{~min}$ at $4{ }^{\circ} \mathrm{C}$. Then, the samples were dewatered with ethanol at increasing concentrations (60.0-99.8\%). The PAs were dried for $24 \mathrm{~h}$ at room temperature and were observed by SEM under the conditions indicated in Section 2.2.

\subsection{Statistical Analysis}

All of the results are expressed as means and standard deviations for experiments performed in at least triplicates. The normality of the measured data was established by the Shapiro-Wilk test. The data were considered normally distributed at $p>0.05$. Multiple comparisons of the data were determined by one-way analysis of variance (ANOVA), where the difference was assumed to be significant at the levels $p \leq 0.05$ and $p \leq 0.01$.

\section{Results and Discussion}

\subsection{Nanomaterials}

In total, 13 nanofibrous PA materials with different morphologies (fiber diameter, surface density, and air permeability) and concentrations of $\mathrm{AgNO}_{3}$ and $\mathrm{CHX}$ were tested (Table 1). PAs n. 1-n. 11 were characterized in the study of Lencova et al. [37], PAs n. 12 and n. 13 were characterized in this study. Examples of CHX PA structures are displayed in Figure 1. Among the most important parameters for evaluating a PA's potential for practical use are the material morphology (incl. fiber diameter, surface density, porosity, air permeability, etc.) and homogeneity, indicating the overall material's quality, mechanical properties, and water absorption. PA enables the production of homogenous structures with precise fiber diameters and similar pore sizes. These properties were confirmed for PAs n. 1-n. 11 [37] as well as the CHX PAs (Figure 1), where homogeneity, uniform, and evenly distributed fibers without any significant deviations or defects were observed. All of the properties are summarized in Table 1. 
Table 1. Characteristics of tested nanomaterials; * materials were characterized within our previous study [37] from which the parameters (antimicrobial compound, surface density, fiber diameter, and air permeability) were taken.

\begin{tabular}{|c|c|c|c|c|c|c|}
\hline $\begin{array}{l}\text { Material } \\
\text { Number }\end{array}$ & Material & $\begin{array}{l}\text { Antimicrobial } \\
\text { Compound }\end{array}$ & $\begin{array}{c}\text { Surface } \\
\text { Density }\left(\mathrm{g} / \mathrm{m}^{2}\right)\end{array}$ & $\begin{array}{l}\text { Fiber Diameter } \\
(\mathrm{nm})\end{array}$ & $\begin{array}{c}\text { Air Permeability } \\
\left(\mathrm{L} / \mathrm{m}^{2} / \mathrm{s}\right)\end{array}$ & $\begin{array}{c}\text { Mean Pore } \\
\text { Diameter (nm) }\end{array}$ \\
\hline $1^{*}$ & $\mathrm{PA} 8 \% 2 \mathrm{~g} / \mathrm{m}^{2}$ & - & $2.4 \pm 0.3$ & $87.7 \pm 18.8$ & $11.1 \pm 1.2$ & $222.7 \pm 28.5$ \\
\hline $2^{*}$ & PA $8 \% 5 \mathrm{~g} / \mathrm{m}^{2}$ & - & $5.2 \pm 0.5$ & $87.7 \pm 18.8$ & $4.3 \pm 0.3$ & $222.7 \pm 28.5$ \\
\hline $3^{*}$ & PA $8 \% 12 \mathrm{~g} / \mathrm{m}^{2}$ & - & $12.1 \pm 0.1$ & $87.7 \pm 18.8$ & $1.7 \pm 0.2$ & $222.7 \pm 28.5$ \\
\hline $4^{*}$ & PA $15 \% 2 \mathrm{~g} / \mathrm{m}^{2}$ & - & $2.1 \pm 0.1$ & $236.2 \pm 66.0$ & $38.8 \pm 2.1$ & $477.5 \pm 132.8$ \\
\hline $5^{*}$ & PA $15 \% 5 \mathrm{~g} / \mathrm{m}^{2}$ & - & $5.3 \pm 0.4$ & $236.2 \pm 66.0$ & $16.0 \pm 11.7$ & $477.5 \pm 132.8$ \\
\hline $6^{*}$ & $\mathrm{PA} 15 \% 11 \mathrm{~g} / \mathrm{m}^{2}$ & - & $11.3 \pm 0.7$ & $236.2 \pm 66.0$ & $9.9 \pm 3.1$ & $477.5 \pm 132.8$ \\
\hline $7^{*}$ & $\mathrm{PA} 15 \% 26 \mathrm{~g} / \mathrm{m}^{2}$ & - & $26.8 \pm 0.8$ & $236.2 \pm 66.0$ & $5.8 \pm 2.1$ & $477.5 \pm 132.8$ \\
\hline $8^{*}$ & $\mathrm{PA} 12 \% 13 \mathrm{~g} / \mathrm{m}^{2}$ & - & $12.7 \pm 0.3$ & $151.7 \pm 41.5$ & $3.8 \pm 0.1$ & $395.8 \pm 128.1$ \\
\hline $9^{*}$ & $\mathrm{PA} 12 \% 10 \mathrm{~g} / \mathrm{m}^{2}$ & $\mathrm{AgNO}_{3} 0.1 \mathrm{wt} \%$ & $10.6 \pm 0.3$ & $141.0 \pm 48.1$ & $3.5 \pm 0.2$ & $331.5 \pm 149.2$ \\
\hline $10^{*}$ & $\mathrm{PA} 12 \% 10 \mathrm{~g} / \mathrm{m}^{2}$ & $\mathrm{AgNO}_{3} 0.3 \mathrm{wt} \%$ & $9.3 \pm 0.3$ & $139.5 \pm 45.8$ & $4.3 \pm 0.2$ & $330.0 \pm 145.0$ \\
\hline $11^{*}$ & $\mathrm{PA} 12 \% 10 \mathrm{~g} / \mathrm{m}^{2}$ & $\mathrm{AgNO}_{3} 0.5 \mathrm{wt} \%$ & $9.3 \pm 0.2$ & $108.0 \pm 23.7$ & $4.6 \pm 0.2$ & $379.0 \pm 167.6$ \\
\hline 12 & $\mathrm{PA} 12 \% 10 \mathrm{~g} / \mathrm{m}^{2}$ & CHX $2.0 w t \%$ & $10.0 \pm 0.7$ & $112.8 \pm 20.2$ & $3.3 \pm 0.3$ & $361.7 \pm 177.9$ \\
\hline 13 & $\mathrm{PA} 12 \% 10 \mathrm{~g} / \mathrm{m}^{2}$ & $\mathrm{CHX} 4.0 \mathrm{wt} \%$ & $9.7 \pm 0.6$ & $108.4 \pm 21.9$ & $3.4 \pm 0.2$ & $401.8 \pm 171.4$ \\
\hline
\end{tabular}

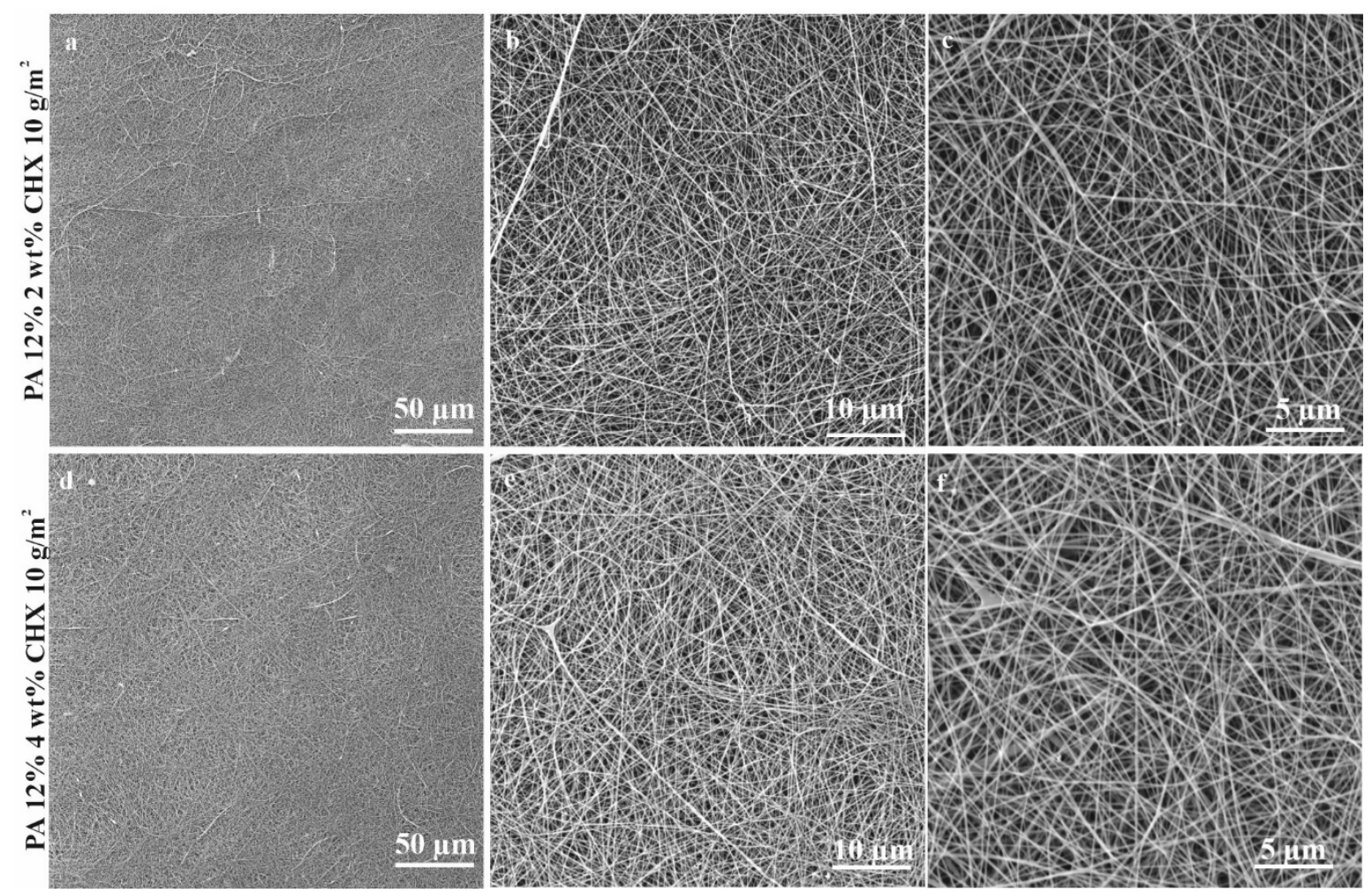

Figure 1. SEM images of used PA nanofibrous materials functionalized with CHX: $2 \mathrm{wt} \% \mathrm{CHX}(\mathbf{a}-\mathbf{c})$ and $4 \mathrm{wt} \% \mathrm{CHX}(\mathbf{d}-\mathbf{f})$ taken at magnifications of $1000 \times(\mathbf{a}, \mathbf{d}), 5000 \times(\mathbf{b}, \mathbf{e})$, and $10,000 \times(\mathbf{c}, \mathbf{f})$.

The permeability of the nanofibrous material is related to its fiber diameter, surface density, and pore size [43]. Permeability was evaluated using an air permeability test (Table 1). As the fiber diameter decreased and the surface density increased, this value decreased. The highest values $\left(38.8 \pm 2.1 \mathrm{~L} / \mathrm{m}^{2} / \mathrm{s}\right)$ were reached for PA n. 4 ; in contrast, the smallest air permeability was measured for the material PA n. 3 .

Suitable pore size, which provides optimal air circulation and guarantees the retention of unwanted microorganisms from the external environment, is essential for wound dressing materials. Pore size can vary enormously depending on the type of material used and the ability to prepare homogenous layers; it always depends on fiber diameter [44]. The pore size of PAs used in our study ranged from 200 to $500 \mathrm{~nm}$, which is less than the 
size of most microbial cells. Therefore, we expected the membranes to retain most of the filtered bacteria. S. aureus used in this study forms round-shaped cells with an approx. size of $0.5-1.5 \mu \mathrm{m}$, which typically clump into grape-like clusters.

Besides the nanomaterial pore size, the other mechanical properties are important for their final use in practice; these are mechanical durability, strength, and maintaining their properties in various environments (dry or wet conditions). The analyzed PAs varied, and nanomaterials with higher surface density had the better mechanical properties and were more easily manipulated. The least suitable was PA $8 \% 2 \mathrm{~g} / \mathrm{m}^{2}$, which ruptured easily and, therefore, should be used with other supporting materials. On the other hand, PA 15\% $26 \mathrm{~g} / \mathrm{m}^{2}$ had the best mechanical durability and could be applied alone.

The other property which cannot be neglected is PA's water absorption, which is approximately $10 \%$ and is determined by the concentration of amide groups. The higher the ratio of $\mathrm{CONH}$ and $\mathrm{CH}_{2}$ groups, the greater the water absorption. The presence of the CONH bond causes PAs to absorb a certain amount of water, depending on their composition. With the increasing number of $\mathrm{CH}_{2}$ groups in the polymer, the amount of absorbed water decreases. Under moist conditions, PAs change their mechanical properties, and their impact strength and ductility increase, but their tensile and bending strength decrease $[4,45]$. During our measurements, it was confirmed that the thinner material absorbed the water faster. Therefore, all of the tested PAs differed in both their wettability and friability depending on their surface density. Based on these findings, we expected the nanomaterials to retain approximately $10 \%$ of the suspension during the experiments due to their absorption properties, and they did.

\subsection{Inhibition Assays and Stability of Functionalized PAs}

Nanomaterials' antimicrobial properties are caused either by the material itself or by the addition of antimicrobial compounds. Whereas PA itself should have no antimicrobial effect [46], we expected $\mathrm{AgNO}_{3}$ or $\mathrm{CHX}$ functionalization to suppress bacterial growth, and this effect will be evident even after a long storage period. CHX has a bactericidal and bacteriostatic effect, especially against Gram-positive bacteria [30], and silver is toxic for both Gram-positive and Gram-negative bacteria [25,26]. The antimicrobial effect of the prepared PAs was measured using two methods:

i. Inhibition zone;

ii. Inhibitory rate.

The inhibition zone method is a standard method used for the determination of antibacterial properties [47,48]; the inhibitory rate is not as common [49], but provides more accurate and evaluable results. The nonfunctionalized PAs (n. 1-n. 8) exhibited no inhibitory effect against $S$. aureus CCM 4516 in both inhibitory tests, and there was no statistical difference between them ( $p \geq 0.05$ ). Thus, PA n. 8 (PA $12 \% 13 \mathrm{~g} / \mathrm{m}^{2}$ ) was chosen as a representative of nonfunctionalized PAs for further comparison.

\subsubsection{Inhibition Zone Method}

Even though the bacterial growth was visibly suppressed under all functionalized PAs (Figure 2), the zones were only apparent for CHX PAs (Table 2). In the literature, CHX antimicrobial activity was primarily studied in connection with other material types. For example, da Silva et al. [50] tested a resin-modified glass-ionomer cement containing 1.25 and $2.50 \%$ CHX and proved its effectiveness against various microorganisms (Streptococcus mutans, Lactobacillus acidophilus, Actinomyces israelii, and Candida albicans). De Carvalho et al. [47] tested the antibacterial activity of cellulose acetate (CA) and polyethylene (PEO) nanofibers containing CHX; the nanofibers successfully inhibited $S$. mutans and Enterococcus faecalis growth. With PA nanofibers, Rysanek et al. [38] studied and confirmed the antibacterial activity of CHX PAs (0.1 wt \% CHX) against various bacteria, including $S$. aureus. 

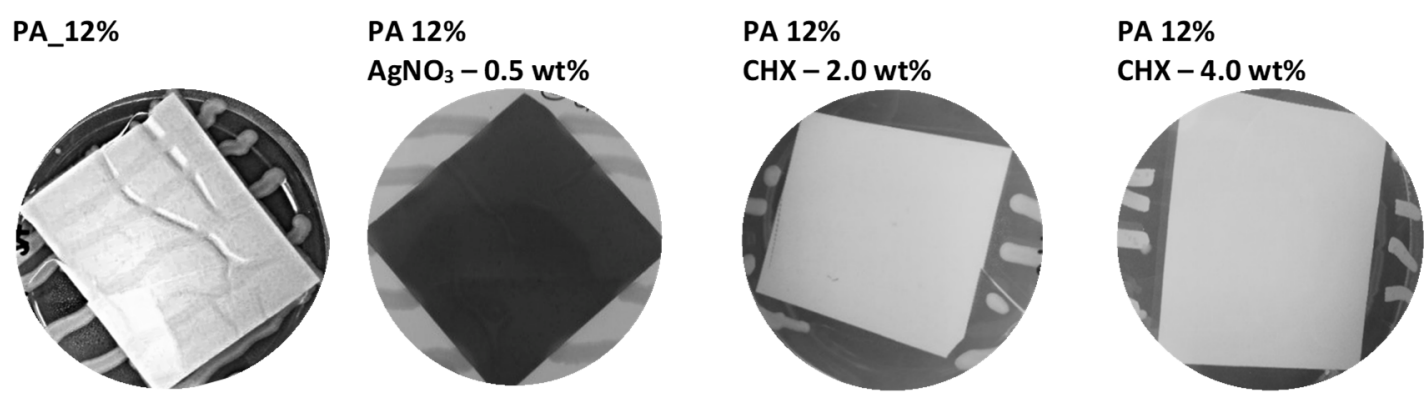

Figure 2. Examples of antibacterial activity test results for PAs n. 8 (PA_12\%), n. 11 (PA 12\% 0.5 wt \% of AgNO 3 ), n. 12 (PA $12 \% 2.0 \mathrm{wt} \% \mathrm{CHX}$ ), n. 13 (PA 12\% $4.0 \mathrm{wt} \%$ CHX), and S. aureus CCM 4516. Around the CHX PAs, the inhibition zones are evident, whereas the other PAs show no inhibition zone. Only for the neat PA can bacterial growth on the material's surface be observed.

Table 2. Average inhibition zones, inhibitory rates, and $\log _{10}$ suppression of PAs n. 8-n. 13 for S. aureus CCM 4516 both shortly (1st analysis) and after nine months (2nd analysis) after PA preparation. Inhibition zones were measured from the edge of the material. " $\mathrm{N}$ " means that the bacterium grew under the PA; " 0 " means that the bacterium did not grow under the PA, but there were no inhibition zones around. $p$-values confirm no significant differences between the 1st and 2nd measurement.

\begin{tabular}{|c|c|c|c|c|c|c|}
\hline \multirow{2}{*}{ Material } & \multicolumn{2}{|c|}{ Inhibition Zones (mm) } & \multicolumn{2}{|c|}{ Inhibitory Rate (\%) } & \multicolumn{2}{|c|}{$\log _{10}$ Suppression $(C F U / m L)$} \\
\hline & 1st Analysis & 2nd Analysis & 1st Analysis & 2nd Analysis & 1st Analysis & 2nd Analysis \\
\hline PA $12 \% 13 \mathrm{~g} / \mathrm{m}^{2}$ & $\mathrm{~N}$ & $\mathrm{~N}$ & $2.0 \pm 1.0$ & $3.0 \pm 1.4$ & $0.0 \pm 0.0$ & $0.0 \pm 0.0$ \\
\hline $\begin{array}{l}\mathrm{PA} 12 \% 10 \mathrm{~g} / \mathrm{m}^{2} \\
\mathrm{AgNO}_{3} 0.1 \mathrm{wt} \%\end{array}$ & $0.0 \pm 0.0$ & $0.0 \pm 0.0$ & $99.2 \pm 0.1$ & $99.5 \pm 0.3$ & $2.2 \pm 0.2$ & $2.5 \pm 0.4$ \\
\hline $\begin{array}{l}\mathrm{PA} 12 \% 10 \mathrm{~g} / \mathrm{m}^{2} \\
\mathrm{AgNO}_{3} 0.3 \mathrm{wt} \%\end{array}$ & $0.0 \pm 0.0$ & $0.0 \pm 0.0$ & $100.0 \pm 0.0$ & $100.0 \pm 0.0$ & $8.0 \pm 0.1$ & $7.5 \pm 0.6$ \\
\hline $\begin{array}{l}\mathrm{PA} 12 \% 10 \mathrm{~g} / \mathrm{m}^{2} \\
\mathrm{AgNO}_{3} 0.5 \mathrm{wt} \%\end{array}$ & $0.0 \pm 0.0$ & $0.0 \pm 0.0$ & $100.0 \pm 0.0$ & $100.0 \pm 0.0$ & $8.7 \pm 0.3$ & $8.6 \pm 0.4$ \\
\hline $\begin{array}{c}\text { PA } 12 \% 10 \mathrm{~g} / \mathrm{m}^{2} \\
\text { CHX } 2.0 \mathrm{wt} \%\end{array}$ & $1.8 \pm 0.1$ & $1.6 \pm 0.2$ & $100.0 \pm 0.0$ & $100.0 \pm 0.0$ & $8.9 \pm 0.0$ & $8.9 \pm 0.0$ \\
\hline $\begin{array}{c}\text { PA } 12 \% 10 \mathrm{~g} / \mathrm{m}^{2} \\
\text { CHX } 4.0 \mathrm{wt} \%\end{array}$ & $2.9 \pm 0.2$ & $2.4 \pm 0.3$ & $100.0 \pm 0.0$ & $100.0 \pm 0.0$ & $8.9 \pm 0.0$ & $8.9 \pm 0.0$ \\
\hline$p$-value $(\alpha=0.05)$ & \multicolumn{2}{|c|}{0.87} & \multicolumn{2}{|c|}{0.98} & \multicolumn{2}{|c|}{0.99} \\
\hline
\end{tabular}

$\mathrm{AgNO}_{3}$-functionalized nanomaterials are common. For example, in the study of Lala et al. [49], inhibition zones of $\mathrm{AgNO}_{3}$-functionalized CA, polyacrylonitrile (PAN), and polyvinylchloride (PVC) nanofibers were observed for E. coli and P. aeruginosa. Similar results were reported in studies focused on the antimicrobial effect of $\mathrm{AgNO}_{3}$-functionalized polyurethane nanofibers against E. coli and Salmonella typhimurium [51] and gelatin nanofibers against $S$. aureus and P. aeruginosa [48]. In the above studies, higher $\mathrm{AgNO}_{3}$ concentrations (5 wt\% [49], 2-10 wt\% [51], and 1-4 wt\% [48]) were used than in our nanomaterials (0.1-0.5 wt\%); therefore, it is not surprising that even when $\mathrm{AgNO}_{3}$ visibly suppressed the growth under the nanomaterial, the zones were not formed.

\subsubsection{Inhibitory Rate Method}

PAs' inhibition effect was further confirmed by the inhibitory rate method (Table 2). The average inhibitory rates ranged from 99.2 to $100.0 \%(p \leq 0.01)$ (Table 2). Except for the inhibitory rates, $\log _{10}$ suppression was determined; it ranged from 2.2 up to $8.9 \mathrm{CFU} / \mathrm{mL}$, which means complete inhibition of bacterial growth. Inhibitory rates and $\log _{10}$ suppressions depended on the concentration of the active substances. With an increasing amount of active substances, the inhibitory rate $/ \log _{10}$ suppression increased, and within the tested concentrations, the CHX PAs had a higher inhibitory effect. These results correspond with the outcomes of the inhibition zone method. 


\subsubsection{Long-Term Stability}

For an even more in-depth analysis, the long-term stability of the PAs was examined by both inhibition assay approaches nine months after their preparation. The obtained results (Table 2) were similar to the results measured within a month after PA production. No significant difference between them was found either by the inhibition zone method or inhibitory rate method ( $p \geq 0.05$ ). The prepared PAs are stable for at least nine months and do not change their antibacterial properties. Furthermore, this also confirmed that electrospinning produces stable and homogeneous nanomaterials. Even though these tests are crucial for confirming the materials' long-term usability without losing their functionality, only a few studies determined their long-term effect. For example, Lala et al. [49] demonstrated the stability of CA-, PAN- and, PVC-functionalized nanofibers by the inhibition zone method after six months.

\subsection{Permeability Assay}

\subsubsection{Filtration Apparatus}

For the testing, a special apparatus (Figure 3) that allowed the filtration of S. aureus CCM 4516 through the PAs was assembled. Its development consisted of various optimization steps, such as selecting a suitable material, designing a suitable shape, comparing different types of gaskets, and the possibility of vacuum generation to enable filtration through low-permeability materials. A similar apparatus was used in the study of Lubasova et al. [9] for E. coli filtration through $\mathrm{PEO}$ and $\mathrm{PEO} /$ purified soy flour (PEO/PSF) nanofibers.
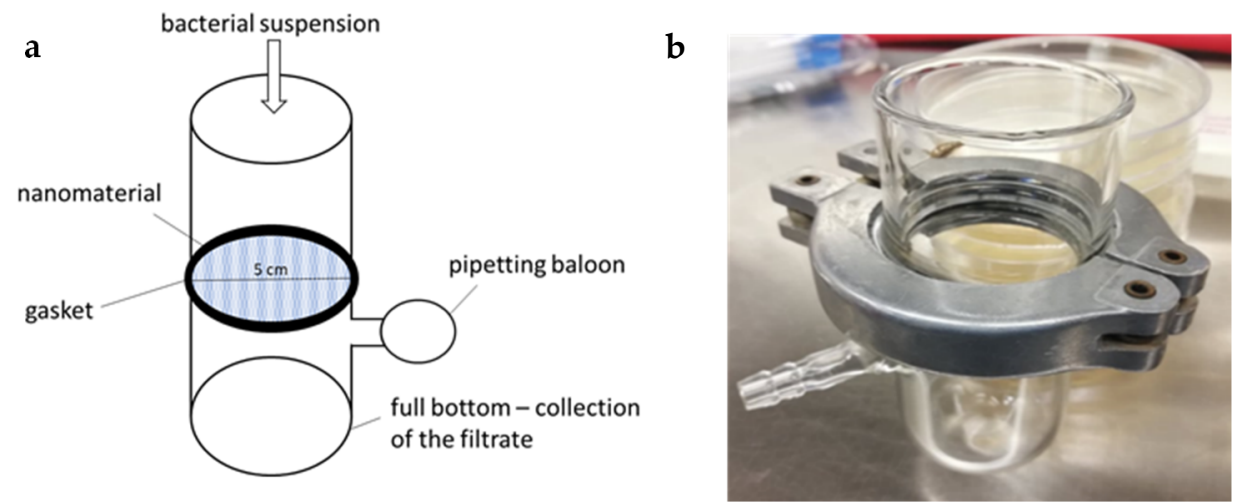

Figure 3. Filtration apparatus used for permeability assay; schema of the apparatus (a); photograph of the final device $(\mathbf{b})$.

Glass was chosen as the most suitable material, which can be reused due to easy sterilization with heat, chemicals (e.g., ethanol), or UV radiation. The shape of the apparatus enabled the suspension to be filtered through the nanomaterial either by gravity or using a vacuum (for example, by a pipetting balloon connected to a side outlet). Of the different tested variants of gaskets, one commonly available in stores proved to be the most suitable in conjunction with sealing rubber. In summary, the resulting apparatus is made up of two straight glass tubes with a round-shaped nanomaterial with a $5 \mathrm{~cm}$ diameter inserted between them, and the two tubes are then joined with a gasket (Figure 3).

\subsubsection{Retention of PAs for Staphylococci Cells}

Due to the properties of nanomaterials, there is the general assumption that they will retain a certain amount of microorganisms depending on their morphology. A reliable filter function was expected for all of the prepared PAs. However, morphology parameters (fiber diameter and surface density) and functionalization can affect their final retention. Therefore, the following hypotheses were drawn up: $\mathrm{H}_{1}$ : all of the PAs will retain most of the filtered bacteria; $\mathrm{H}_{2}$ : fiber diameter and surface density will influence the retention; $\mathrm{H}_{3}$ : the functionalization of PAs will support or increase their ability to retain bacteria. 
The obtained permeability results for the PAs are summarized in Table 3 and Figures 4 and 5 . The enumerated $\log _{10}$ removals $(\mathrm{CFU} / \mathrm{mL})$ and retention rates ranged from 3.3 to 6.8 and from 96.7 to $100.0 \%$, respectively. The majority of PAs achieved 2-log higher retention efficiency (except for PAs n. 1 and n. 4) than microfiltration membranes, which usually achieve $4 \log _{10}$ removal during water filtration [39]. The cultivation of both sides of these PAs used as filters (Figure 4) confirmed that the bacterial cells were reliably captured, and no cells grew on the bottom side (except for PAs n. 1 and n. 4, where several cells grew on the bottom side). Furthermore, SEM analysis (Figure 5) of both sides of PA filters confirmed that bacterial cells did not pass through the materials. Bacterial cells were captured in the structure of the PAs; the images show both individual cells and clusters typical for S. aureus on the filtration side of nanomaterials. On the bottom sides of PAs, none or a few (in the case of PAs n. 1 and n. 4) retained cells were visible. However, retention rates $>96.7 \%$ were achieved for all materials $(100 \%$ is achieved due to a reduction by two or three orders of magnitude [39]).

Table 3. Average $\log _{10}$ removals, retention rates, and visual evaluation of growth on Baird-Parker (BP) agar ("+" means bacterial growth was detected, “_" means bacterial growth was not detected) of PAs for S. aureus CCM 4516.

\begin{tabular}{|c|c|c|c|c|c|}
\hline \multirow{2}{*}{ Material Number } & \multirow{2}{*}{ Material } & \multirow{2}{*}{$\log _{10} \operatorname{Removal}(\mathrm{CFU} / \mathrm{mL})$} & \multirow{2}{*}{ Retention Rate (\%) } & \multicolumn{2}{|c|}{ Growth on BP Agar } \\
\hline & & & & Filtration Side of PA & Bottom Side of PA \\
\hline 1 & $\mathrm{PA} 8 \% 2 \mathrm{~g} / \mathrm{m}^{2}$ & $3.3 \pm 1.6$ & $96.7 \pm 4.6$ & + & + \\
\hline 2 & PA $8 \% 5 \mathrm{~g} / \mathrm{m}^{2}$ & $6.4 \pm 0.5$ & $100.0 \pm 0.0$ & + & - \\
\hline 3 & $\mathrm{PA} 8 \% 12 \mathrm{~g} / \mathrm{m}^{2}$ & $6.7 \pm 0.0$ & $100.0 \pm 0.0$ & + & - \\
\hline 4 & $\mathrm{PA} 15 \% 2 \mathrm{~g} / \mathrm{m}^{2}$ & $4.3 \pm 0.3$ & $100.0 \pm 0.0$ & + & + \\
\hline 5 & PA $15 \% 5 \mathrm{~g} / \mathrm{m}^{2}$ & $6.7 \pm 0.0$ & $100.0 \pm 0.0$ & + & - \\
\hline 6 & PA $15 \% 11 \mathrm{~g} / \mathrm{m}^{2}$ & $6.7 \pm 0.0$ & $100.0 \pm 0.0$ & + & - \\
\hline 7 & PA $15 \% 26 \mathrm{~g} / \mathrm{m}^{2}$ & $6.5 \pm 0.2$ & $100.0 \pm 0.0$ & + & - \\
\hline 8 & PA $12 \% 13 \mathrm{~g} / \mathrm{m}^{2}$ & $6.4 \pm 0.2$ & $100.0 \pm 0.0$ & + & - \\
\hline 9 & $\begin{array}{l}\mathrm{PA} 12 \% 10 \mathrm{~g} / \mathrm{m}^{2} \\
\mathrm{AgNO}_{3} 0.1 \mathrm{wt} \%\end{array}$ & $6.8 \pm 0.1$ & $100.0 \pm 0.0$ & - & - \\
\hline 10 & $\begin{array}{l}\mathrm{PA} 12 \% 10 \mathrm{~g} / \mathrm{m}^{2} \\
\mathrm{AgNO}_{3} 0.3 \mathrm{wt} \%\end{array}$ & $6.8 \pm 0.1$ & $100.0 \pm 0.0$ & - & - \\
\hline 11 & $\begin{array}{l}\mathrm{PA} 12 \% 10 \mathrm{~g} / \mathrm{m}^{2} \\
\mathrm{AgNO}_{3} 0.5 \mathrm{wt} \%\end{array}$ & $6.8 \pm 0.1$ & $100.0 \pm 0.0$ & - & - \\
\hline 12 & $\begin{array}{c}\text { PA } 12 \% 10 \mathrm{~g} / \mathrm{m}^{2} \\
\text { CHX } 2.0 \mathrm{wt} \%\end{array}$ & $6.7 \pm 0.1$ & $100.0 \pm 0.0$ & - & - \\
\hline 13 & $\begin{array}{c}\text { PA } 12 \% 10 \mathrm{~g} / \mathrm{m}^{2} \\
\text { CHX } 4.0 \mathrm{wt} \%\end{array}$ & $6.8 \pm 0.1$ & $100.0 \pm 0.0$ & - & - \\
\hline
\end{tabular}

\section{$13 \mathrm{~g} / \mathrm{m}^{2}$}

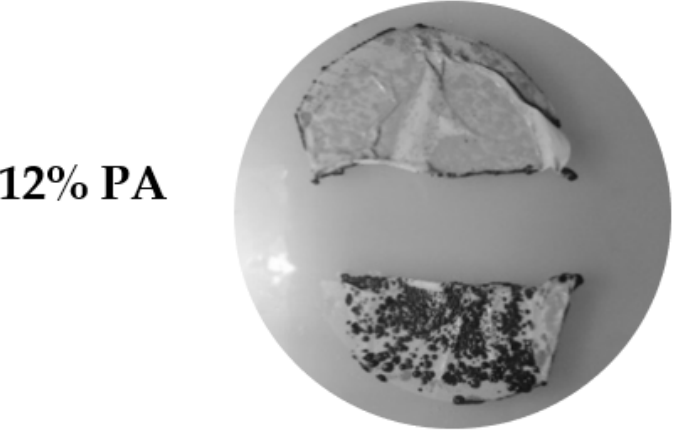

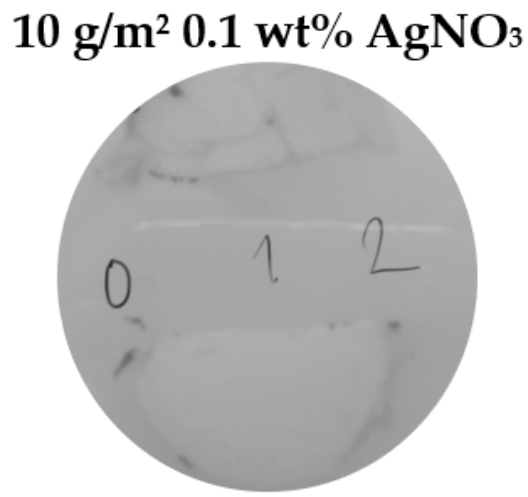

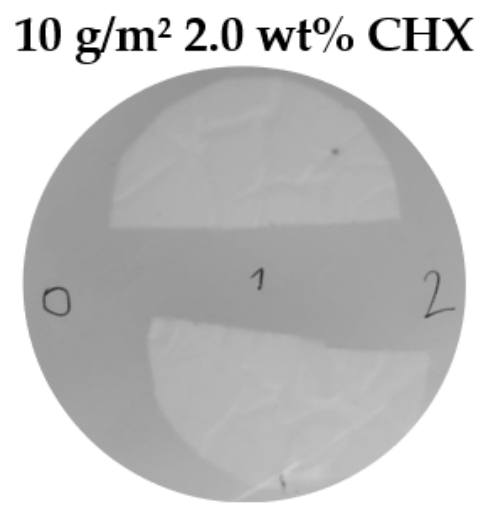

Figure 4. Examples of PAs cultivated at BP agar after the filtration of S. aureus CCM 4516; half of the PA at the top corresponds to the bottom side through which the suspension was not filtered, and half of the PA at the bottom corresponds to filtration side. The numbers $(0,1,2$, etc.) denote individual decimal dilutions of the final filtrates. 

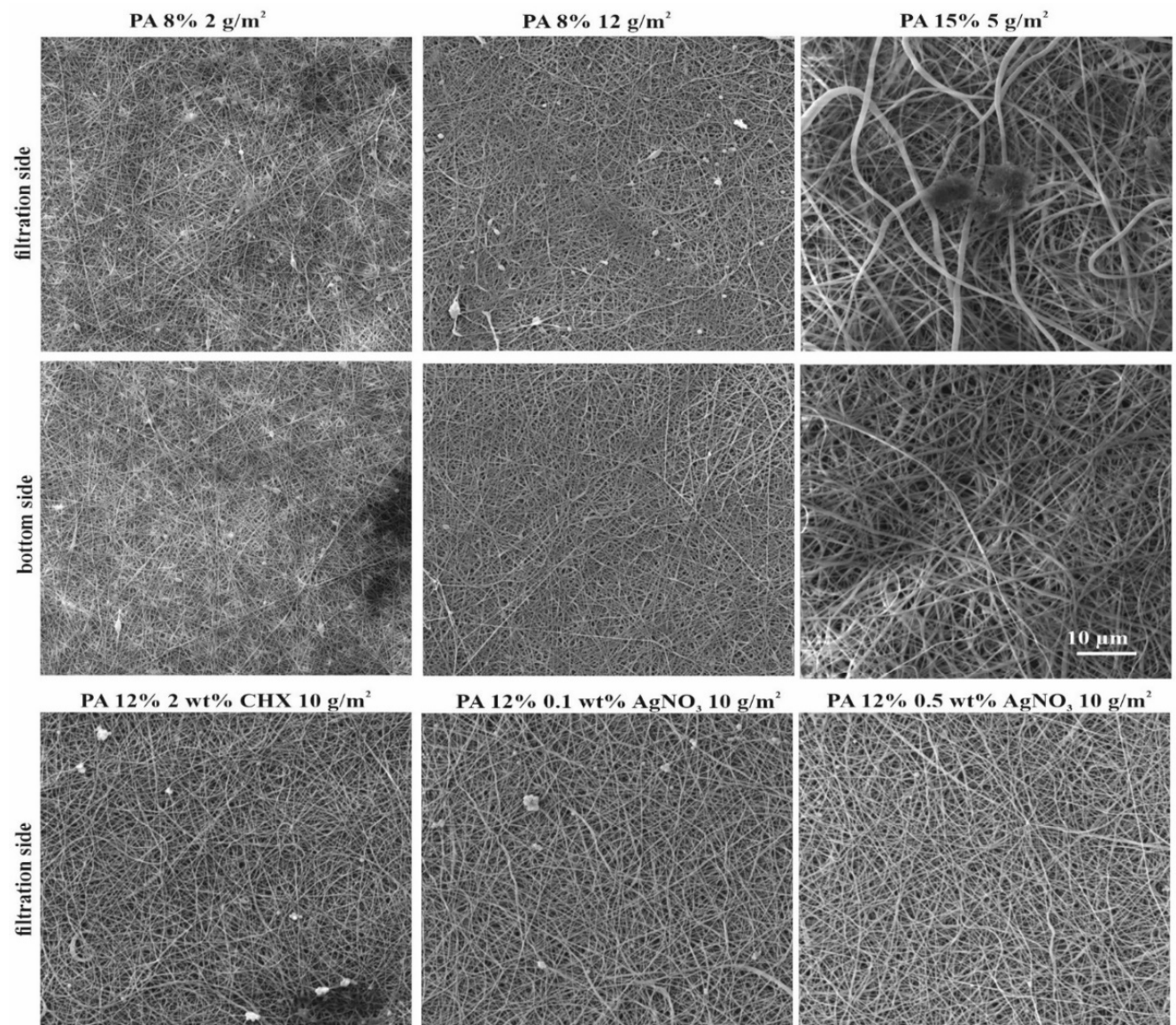

PA $12 \% 0.5$ wt $\%$ AgNO $_{3} 10 \mathrm{~g} / \mathrm{m}^{2}$
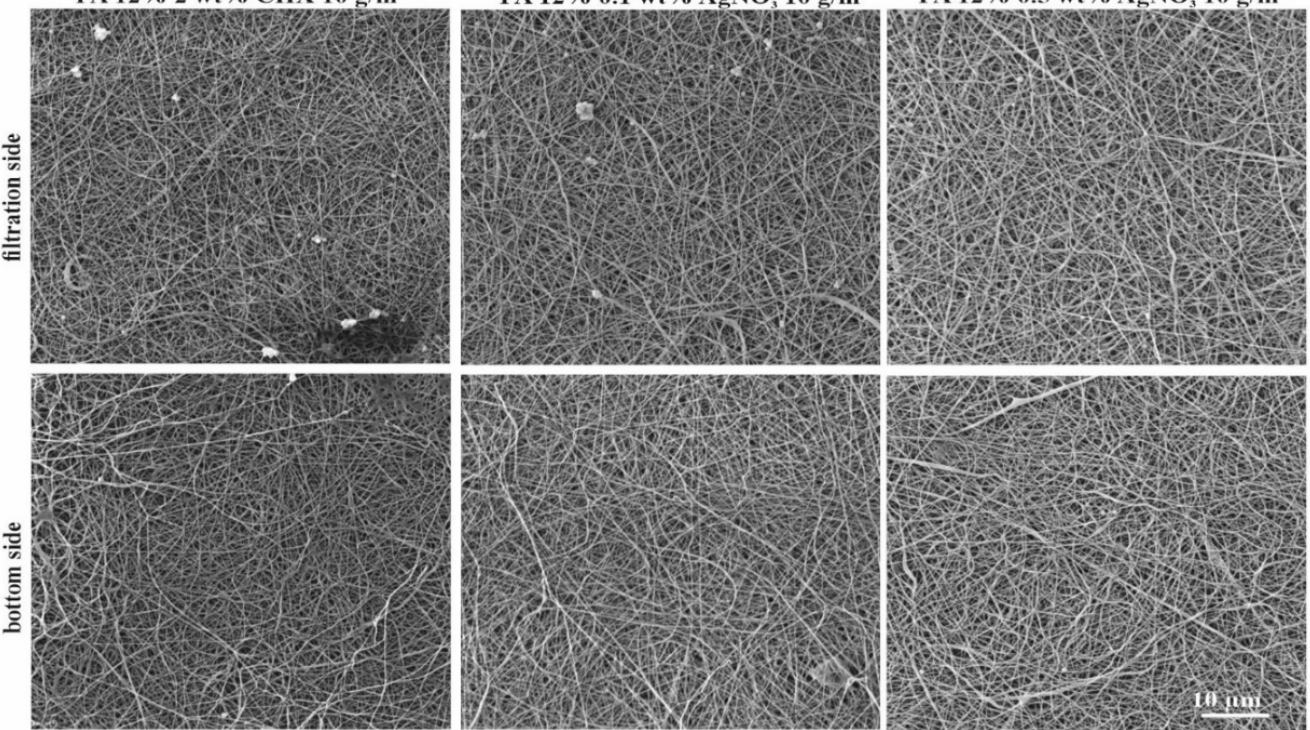

Figure 5. SEM figures of PAs after the filtration of S. aureus CCM 4516 (magnification of 5000×).

Our results are in agreement with other studies dealing with filtration through electrospun PA nanofibers. Most research was focused on the filtration of various inanimate materials, especially dust or aerosol particles. PA6 nonwovens varying in fiber diameter $(50-150 \mathrm{~nm})$ were studied in terms of their air filtration efficiency in the study of Zhang et al. [52]. The results showed PAs to have great potential for high-efficiency particulate air (HEPA) and ultra-low penetration air (ULPA) filters to capture particles $100 \mathrm{~nm}$ or less in diameter [52]. The high filtration efficiency of PAs for dust particles and aerosol particles (100-300 nm in diameter) was demonstrated in the studies of Guibo et al. [33] and Matulevicius et al. [34]. In terms of microbial retention, nylon-6 nanofibrous membranes (NFM) were proven to be effective filtration barriers for S. cerevisiae, F. johnsoniae, and I. fluviatilis in samples of water/broth and beer suspensions [10]. According to tests performed in a dead-end filtration assay, NFMs removed S. cerevisiae and bacterial mixtures completely. In the study of De Vrieze et al. [39], CHX PA nanofibers were tested and found to be effective membranes for water filtration with an efficiency of 4.0-4.2 $\log _{10}$ removal of microorganisms. Our results confirm the high bacterial retention of all the tested PAs $\left(\log _{10}\right.$ removals from 3.3 to 6.8), especially that of PAs with a surface density of $5 \mathrm{~g} / \mathrm{m}^{2}$ or higher $\left(\log _{10}\right.$ removals from 6.4 to 6.8$)$. Although the tests were only performed with one bacterial 
strain, S. aureus CCM 4516, we assume that the materials will be equally effective barriers for other staphylococci strains and other microorganisms of similar or larger size. Thus, PA nanofibers have great potential in all applications requiring high microbial retention.

\subsubsection{Influence of PA Morphology and Functionalization on Their Retention}

Besides overall retention ability, we also focused on the impact of the PA 's morphology parameters (fiber diameter and surface density) and functionalization on their retention. Generally, fiber diameter is considered to be a crucial factor influencing the filtration efficiency of materials $[44,53,54]$ and also plays a role in microbial interactions, mainly cell adhesion and biofilm formation [37,55]. Although the analyzed PAs were made up of three different percentages of PA solutions and thus differed in their fiber diameter (Table 1$)$, there was no significant difference between their retention $(p \geq 0.05)$. This is in contrast to other studies where the smaller particles were filtered. Matulevicius et al. [34] revealed that PA electrospun from $8 \%$ solution with small fiber diameters $(62-66 \mathrm{~nm})$ had the highest filtration efficiency of the six tested polymer concentrations (8-26\%). Guibo et al. [33] evaluated PAs electrospun from 13\% solution as the most efficient of the tested nanomaterials, and even suggested them as references for the industry. In our experiments, staphylococci cells are larger than the size of the particles $(300 \mathrm{~nm})$ filtered in the above-mentioned studies, and, therefore, we suppose that fiber diameter plays a role when smaller particles are filtered.

Besides fiber diameter, surface density is also considered to be important for filtration performance [34,44]. The general assumption is that filtration efficiency increases with increasing surface density, and it decreases with increasing velocity of airflow [53]. $\log _{10}$ removals (Table 3 ) differed within a set of materials prepared from the same polymer solution. Low surface density materials (e.g., PAs n. 1 and n. 4) might not have the same effect as thicker materials (e.g., PAs n. 3 and n. 7), probably due to their mechanical properties. Statistical analysis showed that surface density significantly influenced the retention of the PAs ( $p \leq 0.01$ ), and can be considered to be the most influential factor on a PA's retention ability. The influence of surface density was mentioned by Lubasova et al. [9]; bacterial filtration efficiency by nanofibrous air filters from PEO increased (from 89.0 to 100.0\%) with increasing surface density (from 1.0 to $5.0 \mathrm{~g} / \mathrm{m}^{2}$ ). Matulevicius et al. [34] assumed that high filtration efficiency can be achieved by a suitable combination of fiber diameter and surface density.

In recent research, not only PA, but also PEO [56], polyacrylonitrile (PAN) [57], and polylactide/polyhydroxybutyrate (PLA/PHB) [58] electrospun filters were proven to be suitable filtration membranes. The common shortcoming of these studies is that after filtration, the captured bacteria contaminate the nanomaterial and might cause further biofilm formation $[55,59,60]$. This problem was observed and discussed in detail in the study of Rysanek et al. [38]. However, the biofilm formation can be overcome by proper nanomaterial functionalization, preventing bacterial cell growth $[37,55,61]$. PAs functionalized with $\mathrm{AgNO}_{3}$ and $\mathrm{CHX}$ were also tested. These materials achieved 100.0\% bacterial retention (on average $6.8 \log _{10}$ removal in CFU/mL, Table 3), and these outcomes did not significantly differ from nonfunctionalized PAs ( $p \geq 0.05)$. Nevertheless, the bacterial cells captured by functionalized PAs were probably so damaged by $\mathrm{AgNO}_{3}$ or $\mathrm{CHX}$ that they did not grow on the PAs placed on the BP agar medium (Figure 4). This finding is supported by SEM (Figure 6), showing the damaged staphylococci cells on PA n. 10. Although the functionalization did not change the bacterial retention, it suppressed bacterial growth and prevented the subsequent production of a biofilm. 


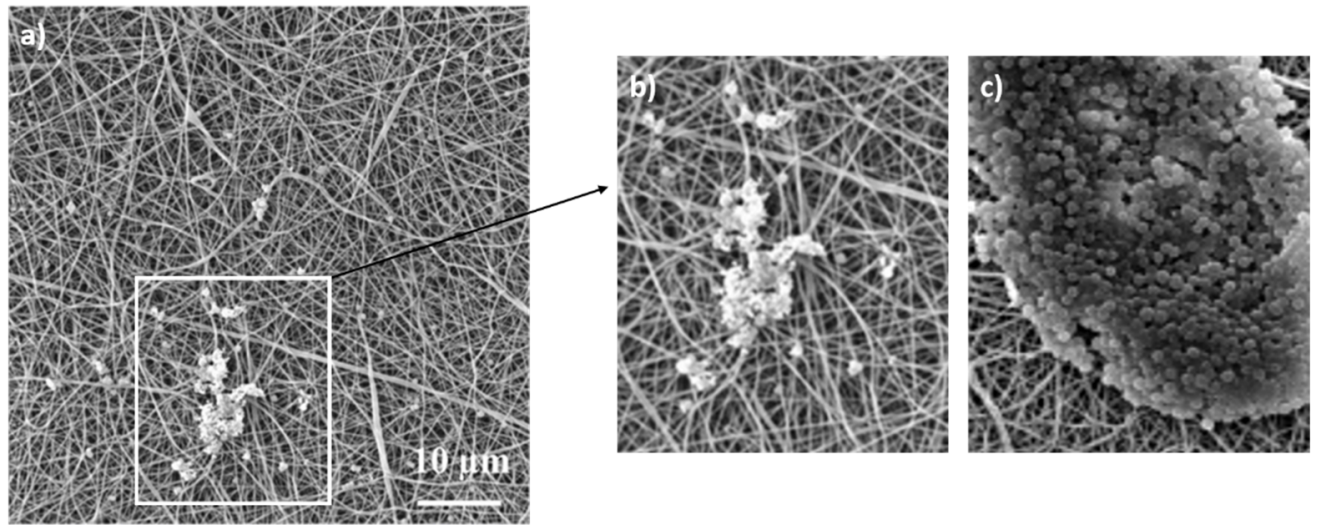

Figure 6. PA $12 \% 0.3 \mathrm{wt} \% \mathrm{AgNO}_{3} 10 \mathrm{~g} / \mathrm{m}^{2}$ after the filtration of $S$. aureus CCM $4516(\mathbf{a}, \mathbf{b})$; silver is toxic for bacterial cells and damages their shape (magnification of 5000×); (a) overall view, (b) detail of damaged bacterial cells, (c) clusters of undamaged S. aureus CCM 4516 cells on nonfunctionalized PA for a comparison with the silver one.

Our results support and expand the knowledge about the interactions between PAs and bacterial cells. To summarize, the following statements can be made:

i. Functionalized PAs have antibacterial properties at all of the tested concentrations of $\mathrm{AgNO}_{3}$ and $\mathrm{CHX}$;

ii. $\quad$ PA $12 \% 10 \mathrm{~g} / \mathrm{m}^{2} \mathrm{CHX} 4.0 \mathrm{wt} \%$ inhibits $S$. aureus CCM 4516 growth completely;

iii. Functionalized PAs are stable for at least nine months after their production;

iv. PA nanomaterials are effective bacterial barriers, which can be used in many applications;

v. Surface density is the crucial morphological parameter influencing PAs' ability to retain staphylococci cells;

vi. The functionalization of $\mathrm{PAs}$ with $\mathrm{AgNO}_{3}$ or $\mathrm{CHX}$ does not change filtration efficiency but makes PA usage safer due to the inhibition of bacterial growth.

In summary, the prepared PA nanomaterials exhibited significant microbiological benefits and can be used in medicine and filtration applications. They can serve as promising wound dressings or materials for the production of surgical masks with potential for the high retention of microorganisms and probably other undesirable particles. For further research, it would be appropriate to test PA nanomaterials when filtering other microorganisms, including viruses.

\section{Conclusions}

For the analysis of interactions between various PA nanofibrous materials and the bacterium $S$. aureus CCM 4516, inhibition and permeability assays were designed and verified. The antibacterial effect of PAs functionalized with $\mathrm{AgNO}_{3}$ and $\mathrm{CHX}$ was confirmed (an inhibition rate of up to $100.0 \%$ and $8.9 \log _{10}$ suppression, which means complete inhibition of bacterial growth); this indicates that the effect of the antibacterial substances is not reduced during the electrospinning process. With increasing concentration of the active substance, the antibacterial efficiency of PAs increased. The most effective PA functionalized with $4.0 \mathrm{wt} \%$ of CHX exhibited the widest inhibition zones on the solidified medium and suppressed bacterial growth completely in the liquid medium. Furthermore, it was proven that functionalized PAs are stable and do not change their antibacterial properties for at least nine months after their production, without the need for specific storage conditions. Next, a glass filtration apparatus enabling the quick and easy filtration of a bacterial suspension through a nanomaterial was constructed. It was found that all of the PA nanofibers have a high bacteria retention ability reaching up to $100.0 \%$ and 6.8 $\log _{10}$ removal, i.e., all filtered cells. Fiber diameter and functionalization did not play a significant role in their efficiency, but surface density was found to be the most influential factor on PAs' retention ability for staphylococci cells. These findings on the overall impact of PAs on S. aureus open the way for many medical applications. The properties of PA 
nanofibers enable their usage in medical devices, such as wound dressings, preventing the spread of infection, and providing highly effective bacterial barriers in other fields. Currently, PAs could be used especially in the development of effective surgical masks limiting the transmission of infectious agents.

Author Contributions: Conceptualization, S.L., K.Z. (Kamila Zdenkova), and H.S.; data curation, S.L. and H.S.; formal analysis, S.L. and H.S.; funding acquisition, V.J. and K.D.; investigation, S.L., K.Z. (Klara Zemanova), R.K., and K.H.; methodology, S.L., K.Z. (Kamila Zdenkova), and V.J.; project administration, K.D.; resources, V.J. and K.D.; supervision, K.D. and H.S.; validation, K.Z. (Kamila Zdenkova) and V.J.; visualization, S.L., K.Z. (Kamila Zdenkova), and V.J.; writing-original draft, S.L. and H.S; writing-review and editing, S.L. All authors have read and agreed to the published version of the manuscript.

Funding: The study was supported by the grant of Specific university research—grant No. A1_FPBT_ 2020_006, funding the methodology development and microbiological analyses, and from the grant of the Technical University of Liberec, project No. SGS-2019-4085, within which the nanofibers were prepared.

Data Availability Statement: Data are available on request to the corresponding author.

Conflicts of Interest: The authors declare no conflict of interest.

\section{References}

1. Simões, D.; Miguel, S.P.; Ribeiro, M.P.; Coutinho, P.; Mendonça, A.G.; Correia, I.J. Recent advances on antimicrobial wound dressing: A review. Eur. J. Pharm. Biopharm. 2018, 127, 130-141. [CrossRef]

2. Bowler, P.G.; Duerden, B.I.; Armstrong, D.G. Wound Microbiology and Associated Approaches to Wound Management. Clin. Microbiol. Rev. 2001, 14, 244-269. [CrossRef]

3. Hawn, M.T.; Vick, C.C.; Richman, J.; Holman, W.; Deierhoi, R.J.; Graham, L.A.; Henderson, W.G.; Itani, K.M.F. Surgical Site Infection Prevention: Time to Move Beyond the Surgical Care Improvement Program. Ann. Surg. 2011, 254. [CrossRef]

4. Cardona, A.F.; Wilson, S.E. Skin and Soft-Tissue Infections: A Critical Review and the Role of Telavancin in Their Treatment. Clin. Infect. Dis. 2015, 61, S69-S78. [CrossRef]

5. Jayakumar, R.; Prabaharan, M.; Kumar, P.S.; Nair, S.; Tamura, H. Biomaterials based on chitin and chitosan in wound dressing applications. Biotechnol. Adv. 2011, 29, 322-337. [CrossRef]

6. Tao, O.; Wu, D.T.; Pham, H.; Pandey, N.; Tran, S.D. Nanomaterials in Craniofacial Tissue Regeneration: A Review. Appl. Sci. 2019, 9, 317. [CrossRef]

7. Krchova, S.; Dzan, L.; Lukas, D.; Mikes, P.; Jencova, V.; Horakova, J.; Pilarova, K. Nanofibers in skin wound healing. Česká Dermatovenerol. 2014, 4, 234-240.

8. S Širc, J.; Hobzová, R.; Kostina, N.; Munzarová, M.; Juklickova, M.; Lhotka, M.; Kubinová, Š.; Zajicova, A.; Michalek, J. Morphological Characterization of Nanofibers: Methods and Application in Practice. J. Nanomater. 2012, 2012, 1-14. [CrossRef]

9. Lubasova, D.; Netravali, A.; Parker, J.; Ingel, B. Bacterial filtration efficiency of green soy protein based nanofiber air filter. J. Nanosci. Nanotechnol. 2014, 14, 4891-4898. [CrossRef] [PubMed]

10. Lemma, S.M.; Esposito, A.; Mason, M.; Brusetti, L.; Cesco, S.; Scampicchio, M. Removal of bacteria and yeast in water and beer by nylon nanofibrous membranes. J. Food Eng. 2015, 157, 1-6. [CrossRef]

11. Sato, A.; Wang, R.; Ma, H.; Hsiao, B.S.; Chu, B. Novel nanofibrous scaffolds for water filtration with bacteria and virus removal capability. QJM Int. J. Med. 2011, 60, 201-209. [CrossRef]

12. Wang, R.; Guan, S.; Sato, A.; Wang, X.; Wang, Z.; Yang, R.; Hsiao, B.S.; Chu, B. Nanofibrous microfiltration membranes capable of removing bacteria, viruses and heavy metal ions. J. Membr. Sci. 2013, 446, 376-382. [CrossRef]

13. Ma, H.; Hsiao, B.S.; Chu, B. Functionalized electrospun nanofibrous microfiltration membranes for removal of bacteria and viruses. J. Membr. Sci. 2014, 452, 446-452. [CrossRef]

14. Contardi, M.; Heredia-Guerrero, J.A.; Perotto, G.; Valentini, P.; Pompa, P.P.; Spanò, R.; Goldoni, L.; Bertorelli, R.; Athanassiou, A.; Bayer, I.S. Transparent ciprofloxacin-povidone antibiotic films and nanofiber mats as potential skin and wound care dressings. Eur. J. Pharm. Sci. 2017, 104, 133-144. [CrossRef]

15. Monteiro, N.; Martins, M.; Martins, A.; Fonseca, N.A.; Moreira, J.N.; Reis, R.L.; Neves, N.M. Antibacterial activity of chitosan nanofiber meshes with liposomes immobilized releasing gentamicin. Acta Biomater. 2015, 18, 196-205. [CrossRef]

16. Anbazhagan, S.; Thangavelu, K.P. Application of tetracycline hydrochloride loaded-fungal chitosan and Aloe vera extract based composite sponges for wound dressing. J. Adv. Res. 2018, 14, 63-71. [CrossRef] [PubMed]

17. Anisha, B.; Biswas, R.; Chennazhi, K.; Jayakumar, R. Chitosan-hyaluronic acid/nano silver composite sponges for drug resistant bacteria infected diabetic wounds. Int. J. Biol. Macromol. 2013, 62, 310-320. [CrossRef] [PubMed]

18. Augustine, R.; Augustine, A.; Kalarikkal, N.; Thomas, S. Fabrication and characterization of biosilver nanoparticles loaded calcium pectinate nano-micro dual-porous antibacterial wound dressings. Prog. Biomater. 2016, 5, 223-235. [CrossRef] [PubMed] 
19. Raguvaran, R.; Manuja, A.; Manuja, B.K.; Riyesh, T.; Singh, S.; Kesavan, M.; Dimri, U. Sodium alginate and gum acacia hydrogels of zinc oxide nanoparticles reduce hemolytic and oxidative stress inflicted by zinc oxide nanoparticles on mammalian cells. Int. J. Biol. Macromol. 2017, 101, 967-972. [CrossRef] [PubMed]

20. Archana, D.; Singh, B.K.; Dutta, J.; Dutta, P. In Vivo evaluation of chitosan-PVP-titanium dioxide nanocomposite as wound dressing material. Carbohydr. Polym. 2013, 95, 530-539. [CrossRef]

21. Venkatasubbu, G.D.; Anusuya, T. Investigation on Curcumin nanocomposite for wound dressing. Int. J. Biol. Macromol. 2017, 98, 366-378. [CrossRef]

22. Güneş, S.; Tihmınlığlu, F. Hypericum perforatum incorporated chitosan films as potential bioactive wound dressing material. Int. J. Biol. Macromol. 2017, 102, 933-943. [CrossRef] [PubMed]

23. Rossi, S.; Marciello, M.; Sandri, G.; Ferrari, F.; Bonferoni, M.C.; Papetti, A.; Caramella, C.; Dacarro, C.; Grisoli, P. Wound Dressings Based on Chitosans and Hyaluronic Acid for the Release of Chlorhexidine Diacetate in Skin Ulcer Therapy. Pharm. Dev. Technol. 2007, 12, 415-422. [CrossRef] [PubMed]

24. Ambrogi, V.; Pietrella, D.; Nocchetti, M.; Casagrande, S.; Moretti, V.; De Marco, S.; Ricci, M. Montmorillonite-chitosanchlorhexidine composite films with antibiofilm activity and improved cytotoxicity for wound dressing. J. Colloid Interface Sci. 2017, 491, 265-272. [CrossRef] [PubMed]

25. Jung, W.K.; Koo, H.C.; Kim, K.W.; Shin, S.; Kim, S.H.; Park, Y.H. Antibacterial Activity and Mechanism of Action of the Silver Ion in Staphylococcus aureus and Escherichia coli. Appl. Environ. Microbiol. 2008, 74, 2171-2178. [CrossRef] [PubMed]

26. Dakal, T.C.; Kumar, A.; Majumdar, R.S.; Yadav, V. Mechanistic Basis of Antimicrobial Actions of Silver Nanoparticles. Front. Microbiol. 2016, 7, 1831. [CrossRef]

27. Ruschulte, H.; Franke, M.; Gastmeier, P.; Zenz, S.; Mahr, K.H.; Buchholz, S.; Hertenstein, B.; Hecker, H.; Piepenbrock, S. Prevention of central venous catheter related infections with chlorhexidine gluconate impregnated wound dressings: A randomized controlled trial. Ann. Hematol. 2009, 88, 267-272. [CrossRef] [PubMed]

28. Groppo, F.; Ramacciato, J.; Simões, R.; Flório, F.; Sartoratto, A. Antimicrobial activity of garlic, tea tree oil, and chlorhexidine against oral microorganisms. Int. Dent. J. 2002, 52, 433-437. [CrossRef]

29. Ülkür, E.; Oncul, O.; Karagoz, H.; Yeniz, E.; Çelik\#xF6;z, B. Comparison of silver-coated dressing (Acticoat ${ }^{\mathrm{TM}}$ ), chlorhexidine acetate $0.5 \%$ (Bactigrass ${ }^{\circledR}$ ), and fusidic acid $2 \%\left(\right.$ Fucidin $\left.^{\circledR}\right)$ for topical antibacterial effect in methicillin-resistant Staphylococcicontaminated, full-skin thickness rat burn wounds. Burns 2005, 31, 874-877.

30. Barbour, M.E.; Maddocks, S.E.; Grady, H.J.; Roper, J.A.; Bass, M.D.; Collins, A.M.; Dommett, R.M.; Saunders, M. Chlorhexidine hexametaphosphate as a wound care material coating: Antimicrobial efficacy, toxicity and effect on healing. Nanomedicine 2016, 11, 2049-2057. [CrossRef]

31. Vianna, M.E.; Gomes, B.P.; Berber, V.B.; Zaia, A.A.; Ferraz, C.C.R.; De Souza-Filho, F.J. In vitro evaluation of the antimicrobial activity of chlorhexidine and sodium hypochlorite. Oral Surg. Oral Med. Oral Pathol. Oral Radiol. Endodontol. 2004, 97, 79-84. [CrossRef]

32. Silvestre, C.; Duraccio, D.; Cimmino, S. Food packaging based on polymer nanomaterials. Prog. Polym. Sci. 2011, 36, 1766-1782. [CrossRef]

33. Guibo, Y.; Qing, Z.; Yahong, Z.; Yin, Y.; Yumin, Y. The Electrospun Polyamide 6 Nanofiber Membranes Used as High Efficiency Filter Materials: Filtration Potential, Thermal Treatment, and Their Continuous Production. J. Appl. Polym. Sci. 2013, 128, 1061-1069. [CrossRef]

34. Matulevicius, J.; Kliucininkas, L.; Martuzevicius, D.; Krugly, E.; Tichonovas, M.; Baltrusaitis, J. Design and Characterization of Electrospun Polyamide Nanofiber Media for Air Filtration Applications. J. Nanomater. 2014, 2014, 1-13. [CrossRef]

35. Chong, E.J.; Phan, T.T.; Lim, I.J.; Zhang, Y.Z.; Bay, B.H.; Ramakrishna, S.; Lim, C.T. Evaluation of electrospun PCL/gelatin nanofibrous scaffold for wound healing and layered dermal reconstitution. Acta Biomater. 2007, 3, 321-330. [CrossRef] [PubMed]

36. Shakespeare, P.G. The role of skin substitutes in the treatment of burn injuries. Clin. Dermatol. 2005, 23, 413-418. [CrossRef]

37. Lencova, S.; Svarcova, V.; Stiborova, H.; Demnerova, K.; Jencova, V.; Hozdova, K.; Zdenkova, K. Bacterial Biofilms on Polyamide Nanofibers: Factors Influencing Biofilm Formation and Evaluation. ACS Appl. Mater. Interfaces 2020, 13, 2277-2288. [CrossRef]

38. Ryšánek, P.; Malý, M.; Čapková, P.; Kormunda, M.; Kolská, Z.; Gryndler, M.; Novák, O.; Hocelíková, L.; Bystrianský, L.; Munzarová, M. Antibacterial modification of nylon-6 nanofibers: Structure, properties and antibacterial activity. J. Polym. Res. 2017, 24, 208.

39. De Vrieze, S.; Daels, N.; Lambert, K.; Decostere, B.; Hens, Z.; Van Hulle, S.; De Clerck, K. Filtration performance of electrospun polyamide nanofibres loaded with bactericides. Text. Res. J. 2011, 82, 37-44. [CrossRef]

40. Qin, N.; Tan, X.; Jiao, Y.; Liu, L.; Zhao, W.; Yang, S.; Jia, A. RNA-Seq-based transcriptome analysis of methicillin-resistant Staphylococcus aureus biofilm inhibition by ursolic acid and resveratrol. Sci. Rep. 2015, 4, 5467. [CrossRef] [PubMed]

41. Horakova, J.; Mikes, P.; Saman, A.; Jencova, V.; Klapstova, A.; Svarcova, T.; Ackermann, M.; Novotny, V.; Suchy, T.; Lukas, D. The effect of ethylene oxide sterilization on electrospun vascular grafts made from biodegradable polyesters. Mater. Sci. Eng. C 2018, 92, 132-142. [CrossRef]

42. Daels, N.; De Vrieze, S.; Sampers, I.; Decostere, B.; Westbroek, P.; Dumoulin, A.; Dejans, P.; De Clerck, K.; Van Hulle, S. Potential of a functionalised nanofibre microfiltration membrane as an antibacterial water filter. Desalination 2011, 275, 285-290. [CrossRef]

43. Liu, Y.-Q.; Feng, J.-W.; Zhang, C.-C.; Teng, Y.; Liu, Z.; He, J.-H. Air permeability of nanofiber membrane with hierarchical structure. Therm. Sci. 2018, 22, 1637-1643. [CrossRef] 
44. Matsumoto, H.; Tanioka, A. Functionality in Electrospun Nanofibrous Membranes Based on Fiber's Size, Surface Area, and Molecular Orientation. Membranes 2011, 1, 249-264. [CrossRef] [PubMed]

45. Monson, L.; Braunwarth, M.; Extrand, C.W. Moisture absorption by various polyamides and their associated dimensional changes. J. Appl. Polym. Sci. 2007, 107, 355-363. [CrossRef]

46. Rogalsky, S.; Bardeau, J.-F.; Wu, H.; Lyoshina, L.; Bulko, O.; Tarasyuk, O.; Makhno, S.; Cherniavska, T.; Kyselov, Y.; Koo, J.H. Structural, thermal and antibacterial properties of polyamide 11/polymeric biocide polyhexamethylene guanidine dodecylbenzenesulfonate composites. J. Mater. Sci. 2016, 51, 7716-7730. [CrossRef]

47. De Carvalho, L.; Peres, B.U.; Maezomo, H.; Shen, Y.; Haapasalo, M.; Manso, A.; Ko, F.; Carvalho, R. Chlorhexidine-containing electrospun nanofibers: Effect of production mode on chlorhexidine release. Dent. Mater. 2017, 33, e17-e18. [CrossRef]

48. Xu, X.; Zhou, M. Antimicrobial gelatin nanofibers containing silver nanoparticles. Fibers Polym. 2008, 9, 685-690. [CrossRef]

49. Lala, N.L.; Ramaseshan, R.; Bojun, L.; Sundarrajan, S.; Barhate, R.; Ying-Jun, L.; Ramakrishna, S. Fabrication of nanofibers with antimicrobial functionality used as filters: Protection against bacterial contaminants. Biotechnol. Bioeng. 2007, 97, 1357-1365. [CrossRef]

50. Da Silva, M.E.R.; Danelon, M.; Souza, J.A.S.; Silva, D.F.; Pereira, J.A.; Pedrini, D.; De Camargo, E.R.; Delbem, A.C.B.; Duque, C. Incorporation of chlorhexidine and nano-sized sodium trimetaphosphate into a glass-ionomer cement: Effect on mechanical and microbiological properties and inhibition of enamel demineralization. J. Dent. 2019, 84, 81-88. [CrossRef] [PubMed]

51. Sheikh, F.A.; Barakat, N.A.M.; Kanjwal, M.A.; Chaudhari, A.A.; Jung, I.-H.; Lee, J.H.; Kim, H.Y. Electrospun antimicrobial polyurethane nanofibers containing silver nanoparticles for biotechnological applications. Macromol. Res. 2009, 17, 688-696. [CrossRef]

52. Zhang, S.; Shim, W.S.; Kim, J. Design of ultra-fine nonwovens via electrospinning of Nylon 6: Spinning parameters and filtration efficiency. Mater. Des. 2009, 30, 3659-3666. [CrossRef]

53. Al-Attabi, R.; Dumée, L.F.; Kong, L.; Schütz, J.A.; Morsi, Y. High Efficiency Poly(acrylonitrile) Electrospun Nanofiber Membranes for Airborne Nanomaterials Filtration. Adv. Eng. Mater. 2018, 20, 1700572. [CrossRef]

54. Zhao, S.; Song, X.; Bu, X.; Zhu, C.; Wang, G.; Liao, F.; Yang, S.; Wang, M. Polydopamine dots as an ultrasensitive fluorescent probe switch for Cr(VI)in vitro. J. Appl. Polym. Sci. 2017, 134, 44784. [CrossRef]

55. Abrigo, M.; Kingshott, P.; McArthur, S.L. Electrospun Polystyrene Fiber Diameter Influencing Bacterial Attachment, Proliferation, and Growth. ACS Appl. Mater. Interfaces 2015, 7, 7644-7652. [CrossRef] [PubMed]

56. Patanaik, A.; Jacobs, V.; Anandjiwala, R.D. Performance evaluation of electrospun nanofibrous membrane. J. Membr. Sci. 2010, 352, 136-142. [CrossRef]

57. Yun, K.M.; Hogan, C.J.; Matsubayashi, Y.; Kawabe, M.; Iskandar, F.; Okuyama, K. Nanoparticle filtration by electrospun polymer fibers. Chem. Eng. Sci. 2007, 62, 4751-4759. [CrossRef]

58. Nicosia, A.; Gieparda, W.; Foksowiczflaczyk, J.; Walentowska, J.; Wesolek, D.; Vazquez, B.; Prodi, F.; Belosi, F. Air filtration and antimicrobial capabilities of electrospun PLA/PHB containing ionic liquid. Sep. Purif. Technol. 2015, 154, 154-160. [CrossRef]

59. Mortimer, C.; Burke, L.; Wright, C. Microbial Interactions with Nanostructures and their Importance for the Development of Electrospun Nanofibrous Materials used in Regenerative Medicine and Filtration. J. Microb. Biochem. Technol. 2016, 8, 195-201. [CrossRef]

60. Tamayo-Ramos, J.A.; Rumbo, C.; Caso, F.; Rinaldi, A.; Garroni, S.; Notargiacomo, A.; Romero-Santacreu, L.; Cuesta-López, S. Analysis of Polycaprolactone Microfibers as Biofilm Carriers for Biotechnologically Relevant Bacteria. ACS Appl. Mater. Interfaces 2018, 10, 32773-32781. [CrossRef]

61. Kurinčič, M.; Jeršek, B.; Klančnik, A.; Možina, S.S.; Fink, R.; Dražić, G.; Raspor, P.; Bohinc, K. Effects of natural antimicrobials on bacterial cell hydrophobicity, adhesion, and zeta potential/Vpliv naravnih protimikrobnih snovi na bakterijsko hidrofobnost, adhezijo in zeta potencial. Arch. Ind. Hyg. Toxicol. 2016, 67, 39-45. [CrossRef] [PubMed] 